\title{
Atmospheric deposition and lake chemistry trends at a high mountain site in the eastern Alps
}

\author{
Danilo TAIT* and Bertha THALER \\ Laboratorio Biologico, Agenzia Provinciale per la Protezione dell'Ambiente, I-39055 Laives, Italy \\ Biologisches Labor der Landesagentur für Umwelt, Unterbergstraße 2, I-39055 Leifers, Italy \\ *e-mail corresponding author: danilo.tait@ provinz.bz.it
}

\begin{abstract}
Records of atmospheric precipitation chemistry starting in 1983 and a series of limnological investigations at two high mountain reference lakes starting in 1988 enable us to describe the response of lake water chemistry to changes in precipitation chemistry and climate. The lakes are located at an altitude well above the timberline in a watershed composed of acidic rocks. Despite the observed reduction in the sulphur atmospheric deposition, the reference lakes showed no corresponding decline in sulphate concentrations, but a marked increase in the acid neutralising capacity was apparent. Changes of the seasonal distribution pattern of the precipitation amounts and a general increase of the air temperature have likely produced an increased weathering which increased the concentration of many inlake solutes and drove the lakes toward more buffered conditions. This phenomenon superimposed to changes like other physical factors (radiation), nutritional conditions and biological factors (enhanced production, competition, predation) has produced in the last years greater modifications than merely those to be expected from the decreased acidic input.
\end{abstract}

Key words: mountain lakes; acidification; anthropogenic factors; chemical limnology; South Tyrol; pollutant deposition

\section{INTRODUCTION}

Acidification of surface waters in Europe due to anthropogenic deposition led to an interest in assessing the regional extent of the phenomenon and subsequently to an interest in documenting the effects that deposition changes have on surface water quality. Although the impact of acid deposition has not induced serious damage to lakes in the province of Bolzano-Bozen (South Tyrol), the results of an extensive survey showed that many high mountain lakes have low alkalinity and are therefore sensitive to acidic inputs (Thaler et al. 1991). The Biological Laboratory of the Enviromental Agency of the Province of Bolzano-Bozen has recorded the atmospheric precipitation chemistry since 1983 and in 1984 set up a programme at its limnological section with the specific aim to assess the state of acidification of remote high altitude lakes in South Tyrol. Since then limnological analyses of two lakes selected among the studied pool have been carried out repeatedly, so that a relatively long term record is available. The purpose of this study is to describe the temporal variations for both atmospheric precipitation and lakewater chemistry. The investigation has been partly carried out in the frame of several European co-operative research projects (ICPIM International Cooperative Programme on Integrated Monitoring, ALPE "Acidification of mountain lakes: Palaeolimnology and Ecology", MOLAR "Mountain Lakes Research").

\section{METHODS}

\subsection{Study area}

Langsee (Lago Lungo) and Milchsee (Lago di Latte), the two lakes selected for long term ecological investigations, lie on acidic rocks in the area of the Texel (Tessa) Mountain Group, in the vicinity of the town of Meran (Tab. 1, Fig. 1). The prevailing rocks in the watersheds are gneiss $(50 \%)$, migmatite $(6 \%)$, paragneiss (1\%) and detritus (39\%) for Milchsee and gneiss $(40 \%)$, paragneiss $(9 \%)$, migmatite $(5 \%)$, amphiboles (1\%) and detritus (33\%) for Langsee. Glaciers cover $30 \%$ of the watershed of Milchsee and $10 \%$ of the watershed of Langsee. The watershed of Milchsee is composed for $35 \%$ of bare rocks and has no alpine pasture, while bare rocks cover $20 \%$ and alpine pasture $8 \%$ of the watershed of Langsee. Both lakes lie well above timberline and the rest of their watersheds is covered by lower plants growing on rocks and stone debris. The upper lake is smaller and lies within the watershed of the lower, deeper and greater lake (Fig. 2). The outlet of Milchsee flows into Langsee.

Tab. 1. Main morphometric and geographic parameters of the two investigated lakes.

\begin{tabular}{lcc}
\hline & Langsee & Milchsee \\
\hline Altitude (m a.s.l.) & 2384 & 2540 \\
Longitude (East) & $11^{\circ} 05^{\prime} 00^{\prime \prime}$ & $11^{\circ} 04^{\prime} 21^{\prime \prime}$ \\
Latitude (North) & $46^{\circ} 43^{\prime} 36^{\prime \prime}$ & $46^{\circ} 43^{\prime} 32^{\prime \prime}$ \\
Lake surface area $\left(\mathrm{km}^{2}\right)$ & 0.2005 & 0.0234 \\
Watershed $\left(\right.$ lake included) $\left(\mathrm{km}^{2}\right)$ & 2.070 & 0.654 \\
Volume $\left(10^{3} \mathrm{~m}^{3}\right)$ & 2583 & 125 \\
Max. depth $(\mathrm{m})$ & 45.0 & 12.3 \\
Mean depth $(\mathrm{m})$ & 12.8 & 5.3 \\
\hline
\end{tabular}

\subsection{Methods}

The analytical methods used, suitable for very soft waters, have been agreed within the research groups involved in the European projects (EMEP 1996; ICP-IM 
Programme Centre 1998), and are listed in table 2 along with the changes which have inevitably occurred during the long investigation period. The laboratory has participated, before and during the period of the present research, in periodical, national and international intercalibration exercises both for acid rain and freshwater analyses (Mosello et al. 1998; Marchetto et al. 1999). The quality control implemented program is described in the reports resulting from the research projects (Wathne et al. 1995).

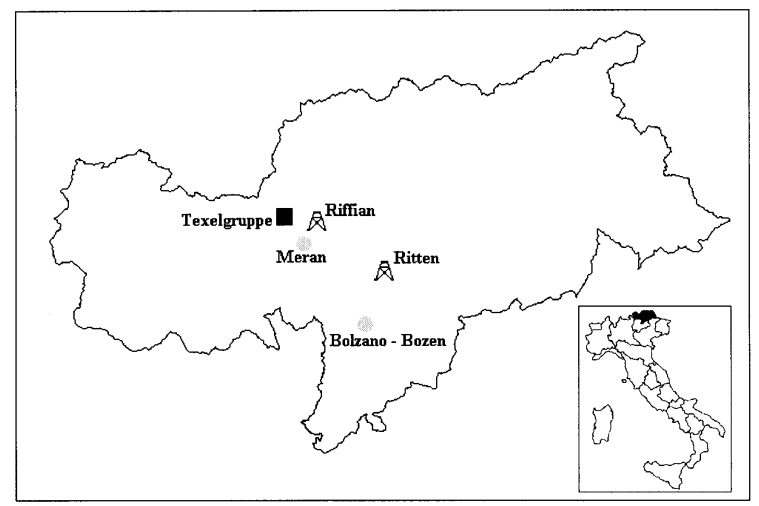

Fig. 1. Lakes' location (filled square) and precipitation sampling sites at Texelgruppe, Riffian and Ritten and location of major cities (circles).

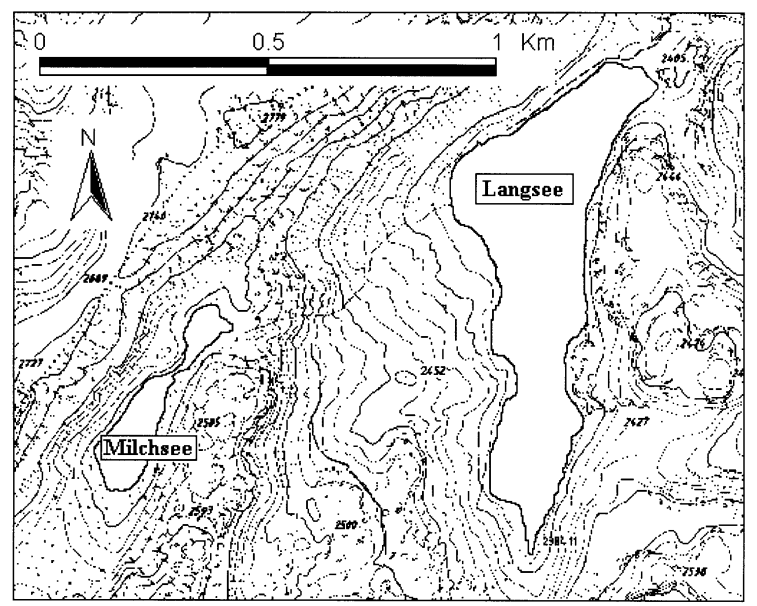

Fig. 2. Map of the lakes.

\subsubsection{Precipitation chemistry}

The monitoring of the deposition chemistry started in the province of Bolzano in 1983 at four sites with bulk sampling (Bendetta 1987). The first wet sampling station was set up in 1985 . The precipitation sampling sites considered in this study are: i) Ritten (Renon), located at $31 \mathrm{~km}$ distance from the lakes at $1780 \mathrm{~m}$ altitude, ii) Riffian (Rifiano), located at a distance of $7 \mathrm{~km}$ and at $1340 \mathrm{~m}$ altitude and iii) Texel located close to the studied lakes at $2390 \mathrm{~m}$ altitude (Fig. 1). Atmospheric precipitation samples were collected weekly at Ritten and at Riffian, while collection of bulk samples from the site Texel occurred at irregular intervals between one to three months. For the site Ritten, which is one of the four Italian stations of the ICP-IM monitoring program, continuous annual bulk and wet analytic series are available since 1985 and 1990, respectively. For the sites Riffian and Texel analyses of bulk samples started in 1996. Trend analyses were performed on volume weighted monthly averages.

\subsubsection{Lakes}

Limnological investigations of the lakes were carried out from 1988 to 1998 with irregular sampling frequency per year and two previous samplings were performed for Langsee in 1984 and 1986. Samples were taken at the deepest part of the lake at representative depths. Temperature and oxygen were measured for the whole water column with a probe, while $\mathrm{pH}$, conductivity, chlorophyll- $a$, major ions and nutrients were analysed in samples taken at five to nine different depths. Volume weighted means for chemical variables were calculated.

\section{RESULTS AND DISCUSSION}

\subsection{Precipitation chemistry}

The annual precipitation amount recorded at the site Ritten, from 1985 to 1998 ranged between 775 and 1175 $\mathrm{mm}$, with a mean value of $980 \mathrm{~mm}$. Acidic deposition is lower than in other sites of Central Europe also because of the relatively low amount of precipitation typical for the area. The concentrations of the substances analysed in atmospheric depositions weekly samples are reported as annual averages for the last three year period in table 3 . The values show small differences between Texel and Ritten and prove that the site Ritten, where a long series of data is available, can well be considered representative for the lakes' watershed, despite the difference in altitude. The values for ammonium, sodium, potassium and chloride registered at the site Riffian suggest local disturbance (agriculture, bird droppings) and are not representative for high altitude precipitation in South Tyrol.

The median $\mathrm{pH}$ value of wet precipitation ranged from 1990 to 1998 between 4.80 and 5.22. These values show that the precipitation in the province has low acidity in comparison with the $\mathrm{pH}$ median values recorded in north-western Italy (Piedmont and Lombardy) and in Canton Ticino, Switzerland where they ranged from slightly above 4.0 to 4.3-4.4 (Mosello \& Marchetto 1996). It must however be noted that all these $\mathrm{pH}$ median values are obtained from weekly samples and are therefore generally higher than those obtained from single precipitations because lighter falls rich in acidic substances are diluted by any other fall which may occur during the week. 
Tab. 2. Analytical methods used.

\begin{tabular}{lcll}
\hline Variables & Years & Method & References \\
\hline pH & $1983-98$ & Potentiometric & \\
Conductivity & $1983-98$ & Potentiometric & \\
Alkalinity & $1983-98$ & Gran titration & Gran 1952 \\
Sulphate & $1983-89$ & Turbidimetric & I.R.S.A., (1972). \\
& $1990-98$ & Ion cromatography & \\
Nitrate & $1983-89$ & Spectrophotometric & Müller \& Widemann 1955 \\
& $1990-98$ & Ion cromatography & \\
Chloride & $1983-90$ & Titration with Ag nitrate & A.P.H.A. 1971 \\
& & (after known Cl addition) & \\
Ammonium & $1990-98$ & Ion cromatography & \\
Ca, Mg, Na, K & $1983-98$ & Spectrophotometric & Wagner 1969 \\
& $1983-92$ & Atomic Absorption & \\
Phosphor & $1993-98$ & AAS or ion cromatography & \\
Silica & $1983-98$ & Spectrophotometry & Vogler 1965, 1966 \\
Chlorophyll & $1983-98$ & Spectrophotometry & Goltermann 1971 \\
\hline
\end{tabular}

Tab. 3. Average annual concentrations in weekly atmospheric depositions at Ritten, Texel and Riffian $\left(\mu \mathrm{eq} \mathrm{l}^{-1}\right)$. Averages of the period 1996-1998.

\begin{tabular}{lcccc}
\hline & $\begin{array}{c}\text { Ritten } \\
\text { bulk }\end{array}$ & $\begin{array}{c}\text { Ritten } \\
\text { wet }\end{array}$ & $\begin{array}{c}\text { Texel } \\
\text { bulk }\end{array}$ & $\begin{array}{c}\text { Riffian } \\
\text { bulk }\end{array}$ \\
\hline pH & 5.19 & 5.09 & 5.22 & 5.81 \\
Calcium & 15 & 12 & 14 & 16 \\
Magnesium & 7 & 6 & 6 & 9 \\
Sodium & 6 & 4 & 4 & 10 \\
Potassium & 9 & 2 & 4 & 16 \\
Ammonium & 35 & 24 & 50 & 126 \\
Sulphate & 27 & 24 & 33 & 25 \\
Nitrate & 24 & 20 & 28 & 29 \\
Chloride & 8 & 7 & 7 & 12 \\
\hline
\end{tabular}

Correlations between the solute weekly concentrations measured for the bulk and the wet samples at the same site Ritten show a good agreement for ammonium $(\mathrm{r}=0.58)$, nitrate $(\mathrm{r}=0.82)$ and sulphate $(\mathrm{r}=0.79)$, proving the low contribution of the dust particles. The influence of dust dryfall collected in the bulk collectors is instead a little stronger for calcium $(\mathrm{r}=0.69)$ and magnesium $(\mathrm{r}=0.44)$ and heavy for potassium. Also for $\mathrm{pH}$, higher values were measured for most bulk samples than for wet samples, with differences generally up to 0.1 unit and a correlation coefficient between bulk and wet $\mathrm{H}^{+}$ concentrations equal to 0.32 .

The three main factors influencing precipitation chemistry are anthropogenic air pollution, mineral dust and sea spray. The low concentrations of sodium and chloride, both with a median concentration in the wet samples around $5 \mu \mathrm{mol} \mathrm{l}^{-1}$, show the small influence of sea spray (seasalt) in South Tyrol. Alkaline dust, transported by air masses from the Sahara, is relatively frequent in the atmospheric precipitation of the province and influences mostly the calcium concentrations exerting a buffering action on the acidity of depositions (Psenner 1999). $\mathrm{H}^{+}, \mathrm{SO}_{4}{ }^{=}$and $\mathrm{NO}_{3}{ }^{-}$and heavy metals are generally linked with air pollution. Different sources, natural and anthropogenic, contribute to the emission of ammonia. A cluster analysis showed that sodium and chloride are strongly correlated and there is a cluster grouping sulphate, ammonium and nitrate, the substances mainly deriving from anthropogenic activity, which is closer in the wet than in the bulk values (Fig. $3)$. Hydrogen ion, probably because of the low level of acidic deposition, is not linked to the acidifying substances, but instead to the ions of marine origin and to the cations calcium, magnesium and potassium. This pattern suggests on the one hand that acidic substances are deriving primarily from the south and on the other hand that acidity is buffered by dust.

Acidity of depositions in South Tyrol, as in all the others parts of Italy and to a minor extent also in the regions located north of the Alps, is mitigated by relatively frequent episodes ( 2 to 5 each year) of precipitation with $\mathrm{pH}$ higher than 6.0 due to the transport of alkaline dust. The relationship between $\mathrm{pH}$ and precipitation volume shows no correlation between the two parameters; both minor and major precipitation events can be associated to either low or high $\mathrm{pH}$ values.

Deposition measured at Ritten (bulk and wet) does not differ substantially from that measured at Texel, the site located closely to the studied lakes (Tab. 4). Except for ammonium, bulk deposition values at Texel were more similar to the wet deposition measured at Ritten than to the bulk values. This is probably due to the minor influence of local dust sources, to the higher altitude and the minor anthropical influence. The higher ammonium deposition level could instead either be due to the longer exposition period of the samples or to the influence of the grazing cattle.

The average annual proton flux by wet precipitation registered at Ritten was, during the period 1996-1998, equal to $8.3 \mathrm{meq} \mathrm{m}^{-2} \mathrm{y}^{-1}$. This annual proton input is much lower than the value found in other sites in central 
Europe, southern Norway or Netherlands (Meesenburg \& Müller 1998; Hauhs 1989; Abrahamsen et al. 1989; Mulder et al. 1987). Sulphate deposition measured in 1993 at 23 continental EMEP sites showed an average value of $0.714 \mathrm{~g} \mathrm{~S} \mathrm{~m}^{-2} \mathrm{y}^{-1}$ (Hijelbrekke et al. 1995), while the value measured at the study area for the same period is $0,67 \mathrm{~g} \mathrm{~S} \mathrm{~m}^{-2} \mathrm{y}^{-1}$ and decreased further in the following years. Nitrogen dioxide (nitrate deposition) has, in relation to sulphur dioxide (sulphate deposition), a relevant role in South Tyrol, particularly towards the end of the study period after the decrease of the atmospheric sulphur level.
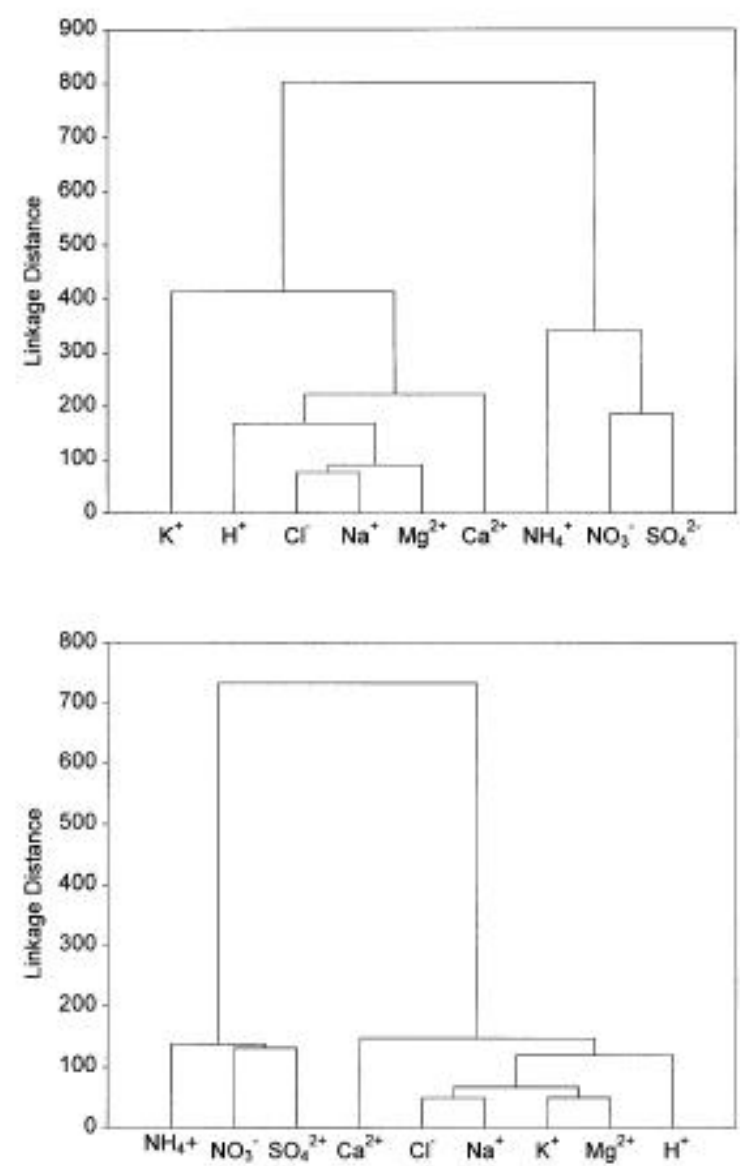

Fig. 3. Tree diagram, Ward's method and euclidean distances, for Ritten bulk (above) and Ritten wet (below).

The seasonal pattern of precipitation amount are similar among the different precipitation sampling sites and are characterised by higher values during the summer months and much lower volumes during winter (Fig. 4). A peak of nitrate, sulphate and calcium concentrations can be observed during spring followed by high values during summer and low values during winter (Tab. 5). Because of the strong seasonality in precipitation (Fig. 4), depositional fluxes of major ions are much higher in summer than in winter.
Tab. 4. Average of the annual weighted mean deposition values (meq $\mathrm{m}^{-2} \mathrm{y}^{-1}$ ) for the period 1996 to 1998 at the sampling sites Ritten and Texel.

\begin{tabular}{lccc}
\hline & Ritten bulk & Ritten wet & Texel bulk \\
\hline Altitude (m a. s. 1.) & 1780 & 1780 & 2390 \\
$\mathrm{H}^{+}$ & 6.0 & 8.3 & 4.6 \\
Sulphate & 32.0 & 24.4 & 25.2 \\
Nitrate & 27.0 & 20.8 & 22.2 \\
Ammonium & 32.6 & 24.2 & 38.2 \\
Chloride & 7.6 & 6.6 & 7.3 \\
Calcium & 15.9 & 12.2 & 10.7 \\
Magnesium & 6.4 & 5.5 & 5.1 \\
\hline
\end{tabular}

\subsection{Lake-water chemistry}

The two investigated lakes lie in watersheds mainly composed of acidic rocks and have similar chemical characteristics but differ strongly in size, depth (Tab. 1) and productivity. Both lakes are acid sensitive. The lakes are ice covered from November to June and reach a maximum temperature of $10-11{ }^{\circ} \mathrm{C}$ in the upper layers during August. The hypolimnetic waters are constantly around $4{ }^{\circ} \mathrm{C}$ in Langsee, while in Milchsee they reach 6 ${ }^{\circ} \mathrm{C}$. Both lakes are well oxygenated although Langsee showed anoxic conditions in the deep water layers during the winter 1997-98. The lakes have low ionic concentrations and conductivity values around $22 \mu \mathrm{S} \mathrm{cm}^{-1}$ at $20{ }^{\circ} \mathrm{C}$ for Milchsee and around $13 \mu \mathrm{S} \mathrm{cm}^{-1}$ for Langsee. Weighted averages for alkalinity are currently around $90 \mu \mathrm{eq} \mathrm{l}^{-1}$ at Milchsee and $50 \mu \mathrm{eq} \mathrm{l}^{-1}$ at Langsee, but were lower in the eighties. These values are well above the critical values of $20 \mu \mathrm{eq} \mathrm{l}^{-1}$ at which organisms start to be affected (Lien et al. 1992).

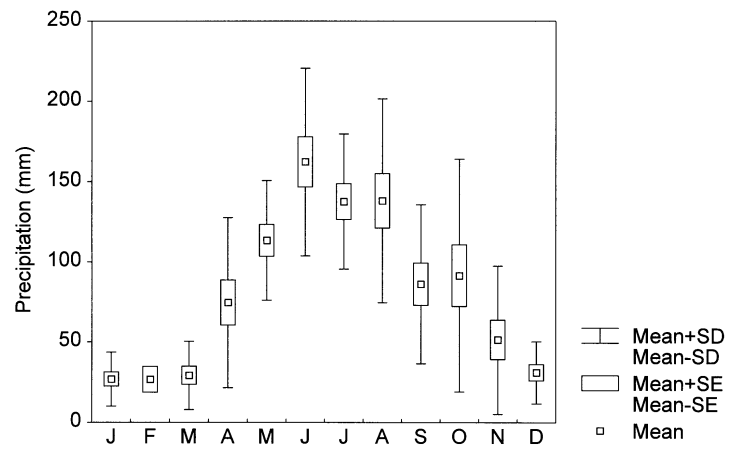

Fig. 4. Monthly precipitation amounts at Ritten during the period 1985 - 1998.

An early limnological investigation of 1935 reports alkalinity values of 180 and $270 \mu \mathrm{eq} 1^{-1}$ for Milchsee and Langsee respectively and a pH of 7.1 and 8.4 (Leutelt-Kipke 1936). Many factors must be considered when recent and historical data are compared: the change in container material, the development of glass electrode for $\mathrm{pH}$ measurements (previously universal indicator was used (Leutelt-Kipke 1934)) and changes 
Tab. 5. Monthly mean values of precipitation amount, conductivity and ion concentrations in bulk and wet precipitation at Ritten and significance of the monthly variations (ANOVA).

$\underline{\text { Ritten bulk 1985-1998 }}$

\begin{tabular}{|c|c|c|c|c|c|c|c|c|c|c|c|}
\hline & $\begin{array}{c}\text { Prec. } \\
\text { mm }\end{array}$ & $\begin{array}{c}\mathrm{H}^{+} \\
\mu \mathrm{eq} \mathrm{l}^{-1}\end{array}$ & $\begin{array}{l}\text { Cond. } \\
\mu \mathrm{S} \mathrm{cm}^{-1}\end{array}$ & $\begin{array}{c}\mathrm{Ca}^{++} \\
\mu \mathrm{eq} 1^{-1}\end{array}$ & $\begin{array}{c}\mathrm{Mg}^{++} \\
\mu e q \mathrm{l}^{-1}\end{array}$ & $\begin{array}{c}\mathrm{Na}^{+} \\
\mu \mathrm{eq} 1^{-1}\end{array}$ & $\begin{array}{c}\mathrm{K}^{+} \\
\mu \mathrm{eq} \mathrm{l}^{-1}\end{array}$ & $\begin{array}{c}\mathrm{NH}_{4}^{+} \\
\mu \text { eq } \mathrm{l}^{-1}\end{array}$ & $\begin{array}{c}\mathrm{NO}_{3}^{-} \\
\mu \mathrm{eq} \mathrm{l}^{-1}\end{array}$ & $\begin{array}{c}\mathrm{SO}_{4}= \\
\mu \mathrm{eq} \mathrm{l}^{-1}\end{array}$ & $\begin{array}{c}\mathrm{Cl}^{-} \\
\mu \mathrm{eq} \mathrm{l}^{-1}\end{array}$ \\
\hline Jan & 24.7 & 16 & 10.4 & 14 & 5 & 6 & 2 & 8 & 18 & 22 & 7 \\
\hline Feb & 25.6 & 36 & 30.7 & 14 & 6 & 7 & 1 & 15 & 30 & 27 & 8 \\
\hline Mar & 30.9 & 26 & 31.0 & 42 & 13 & 14 & 13 & 48 & 72 & 52 & 14 \\
\hline Apr & 77.7 & 16 & 21.7 & 23 & 8 & 5 & 7 & 43 & 45 & 48 & 10 \\
\hline May & 112.4 & 13 & 17.0 & 23 & 7 & 7 & 6 & 46 & 37 & 47 & 12 \\
\hline Jun & 161.9 & 8 & 14.1 & 17 & 9 & 7 & 6 & 50 & 31 & 36 & 9 \\
\hline Jul & 140.7 & 10 & 15.2 & 19 & 8 & 8 & 7 & 46 & 32 & 47 & 10 \\
\hline Aug & 135.0 & 9 & 13.8 & 18 & 6 & 5 & 5 & 44 & 35 & 42 & 11 \\
\hline Sep & 87.6 & 16 & 16.1 & 17 & 8 & 8 & 4 & 39 & 32 & 45 & 8 \\
\hline Oct & 85.7 & 12 & 18.3 & 16 & 6 & 8 & 6 & 20 & 25 & 26 & 8 \\
\hline Nov & 52.1 & 19 & 14.0 & 17 & 8 & 12 & 4 & 18 & 29 & 26 & 11 \\
\hline \multirow[t]{2}{*}{ Dec } & 32.9 & 16 & 11.5 & 4 & 3 & 6 & 2 & 8 & 16 & 16 & 6 \\
\hline & $\mathrm{p}<.0001$ & $\mathrm{p}<.0086$ & $\mathrm{p}<.01618$ & $\mathrm{p}<.0001$ & $\mathrm{p}<.0235$ & $\mathrm{p}<.1506$ & $\mathrm{p}<.5826$ & $\mathrm{p}<.0001$ & $\mathrm{p}<.0001$ & $\mathrm{p}<.0001$ & $\mathrm{p}<.0225$ \\
\hline
\end{tabular}

\section{Ritten wet 1990-1998}

\begin{tabular}{|c|c|c|c|c|c|c|c|c|c|c|c|}
\hline & $\begin{array}{c}\text { Prec. } \\
\text { mm }\end{array}$ & $\begin{array}{c}\mathrm{H}^{+} \\
\mu \mathrm{eq} 1^{-1}\end{array}$ & $\begin{array}{l}\text { Cond. } \\
\mu \mathrm{S} \mathrm{cm}^{-1}\end{array}$ & $\begin{array}{c}\mathrm{Ca}^{++} \\
\mu e q 1^{-1}\end{array}$ & $\begin{array}{c}\mathrm{Mg}^{++} \\
\mu \mathrm{eq} \mathrm{l}^{-1}\end{array}$ & $\begin{array}{c}\mathrm{Na}^{+} \\
\mu \mathrm{eq} \mathrm{l}^{-1}\end{array}$ & $\begin{array}{c}\mathrm{K}^{+} \\
\mu \mathrm{eq} \mathrm{l}^{-1}\end{array}$ & $\begin{array}{c}\mathrm{NH}_{4}^{+} \\
\mu \mathrm{eq} \mathrm{^{-1 }}\end{array}$ & $\begin{array}{c}\mathrm{NO}_{3}^{-} \\
\mu e q 1^{-1}\end{array}$ & $\begin{array}{c}\mathrm{SO}_{4}{ }^{=} \\
\mu e q \mathrm{l}^{-1}\end{array}$ & $\begin{array}{c}\mathrm{Cl}^{-} \\
\mu \mathrm{eq} \mathrm{l}^{-1}\end{array}$ \\
\hline Jan & 16.9 & 16 & 10.2 & 14 & 5 & 9 & 3 & 9 & 19 & 23 & 9 \\
\hline Feb & 10.5 & 26 & 18.4 & 12 & 6 & 6 & 2 & 21 & 31 & 32 & 9 \\
\hline Mar & 21.5 & 22 & 25.2 & 27 & 8 & 10 & 4 & 43 & 61 & 42 & 14 \\
\hline Apr & 57.0 & 15 & 19.7 & 16 & 7 & 6 & 3 & 35 & 37 & 33 & 10 \\
\hline May & 88.8 & 11 & 14.6 & 18 & 6 & 8 & 3 & 45 & 34 & 40 & 11 \\
\hline Jun & 170.3 & 8 & 11.6 & 15 & 6 & 6 & 2 & 42 & 29 & 32 & 9 \\
\hline Jul & 144.0 & 11 & 13.0 & 15 & 6 & 5 & 2 & 38 & 27 & 33 & 7 \\
\hline Aug & 111.4 & 10 & 12.0 & 15 & 5 & 4 & 2 & 37 & 37 & 38 & 11 \\
\hline Sep & 95.5 & 12 & 11.2 & 10 & 5 & 7 & 2 & 29 & 25 & 29 & 6 \\
\hline Oct & 117.1 & 7 & 7.4 & 14 & 5 & 5 & 3 & 11 & 20 & 16 & 5 \\
\hline Nov & 53.0 & 12 & 9.9 & 15 & 5 & 12 & 4 & 10 & 23 & 20 & 12 \\
\hline \multirow[t]{2}{*}{ Dec } & 34.6 & 13 & 10.3 & 6 & 3 & 6 & 1 & 6 & 16 & 11 & 6 \\
\hline & $\mathrm{p}<.0001$ & $\mathrm{p}<.1173$ & $\mathrm{p}<.0008$ & $\mathrm{p}<.0002$ & $\mathrm{p}<.1630$ & $\mathrm{p}<.1568$ & $\mathrm{p}<.3626$ & $\mathrm{p}<.0001$ & $\mathrm{p}<.0005$ & $\mathrm{p}<.0012$ & $\mathrm{p}<.0166$ \\
\hline
\end{tabular}

of the methods for determining alkalinity (previously titration using methylorange (Leutelt-Kipke 1934)). Although taken with caution, these data can give an indication of what could have been the buffering conditions of two lakes the in pre-industrial times. It is surprising that, opposite to the current situation, the reported value for alkalinity was higher for Langsee than for Milchsee.

The low concentration of chloride in both lakewater (Tab. 6) and precipitation (Tab. 3) shows that the influence of sea spray is negligible. It is interesting to note however, that lakewater concentrations are only about $50 \%$ of the precipitation average, while a higher value would be expected because of evapotranspiration. It has been supposed that this is due to a washing out of salts during the early thaw (Camarero et al. 1995). Weighted average for sulphate are presently at 50-70 $\mu \mathrm{eq} \mathrm{l}^{-1}$ higher for Milchsee and lower for Langsee. This value is about twice as high as the recent average concentra- tion in atmospheric precipitation $\left(30 \mu \mathrm{eq} 1^{-1}\right)$. The sulphate/chloride ratio, which is distinctly higher in the lakes than in precipitation, shows that evapotranspiration cannot be made responsible for the sulphate accumulation and that the lakes must be influenced by some sulphur minerals present in the watershed. Results from an extensive survey made on high altitude lakes in the province showed that this is true for most lakes (Thaler et al. 1991). The same survey also showed that alkalinity and $\mathrm{pH}$ are lower in lakes where the percentage of acidic rocks within the watershed is high, and higher where a high percentage of alpine prairie within the watershed is present. On the contrary, nitrate concentrations were higher in lakes with a watershed mainly composed of acidic rocks and lower in lakes with a high percentage of alpine prairie indicating nitrate uptake by the terrestrial vegetation. Nitrate is used also by aquatic microorganisms (in-lake uptake). As a result nitrate concentrations were lower in the lakes than in precipitation 
Tab. 6. Average of the values measured at 1, 3 and $5 \mathrm{~m}$ depth during 1998 for Milchsee and Langsee.

\begin{tabular}{|c|c|c|c|c|c|c|c|c|c|}
\hline & \multirow[b]{2}{*}{ unit } & \multicolumn{4}{|c|}{ Milchsee } & \multicolumn{4}{|c|}{ Langsee } \\
\hline & & Mean & Median & Minimum & Maximum & Mean & Median & Minimum & Maximum \\
\hline $\mathrm{pH}$ & & 6.72 & 6.73 & 5.56 & 7.34 & 6.19 & 6.18 & 5.90 & 6.56 \\
\hline Conductivity & $\mu \mathrm{S} / \mathrm{cm} 20^{\circ} \mathrm{C}$ & 18.79 & 19.51 & 6.70 & 24.10 & 13.54 & 12.82 & 11.49 & 16.24 \\
\hline Hydrogen ion & $\mu e q 1^{-1}$ & 0 & 0 & 0 & 3 & 1 & 1 & 0 & 1 \\
\hline Ammonium & $\mu e q 1^{-1}$ & 3 & 2 & 0 & 18 & 4 & 2 & 1 & 20 \\
\hline Calcium & $\mu e q 1^{-1}$ & 115 & 121 & 20 & 149 & 73 & 74 & 58 & 91 \\
\hline Magnesium & $\mu \mathrm{eq} 1^{-1}$ & 14 & 14 & 5 & 19 & 13 & 12 & 11 & 16 \\
\hline Sodium & $\mu e q 1^{-1}$ & 18 & 18 & 6 & 23 & 16 & 15 & 13 & 23 \\
\hline Potassium & $\mu e q 1^{-1}$ & 9 & 9 & 2 & 12 & 5 & 5 & 5 & 7 \\
\hline Alkalinity & $\mu e q 1^{-1}$ & 88 & 92 & 16 & 106 & 43 & 45 & 24 & 49 \\
\hline Sulphate & $\mu e q 1^{-1}$ & 66 & 66 & 20 & 86 & 59 & 56 & 42 & 79 \\
\hline Nitrate & $\mu e q 1^{-1}$ & 14 & 14 & 12 & 19 & 12 & 8 & 6 & 29 \\
\hline Chlorid & $\mu \mathrm{eq} 1^{-1}$ & 4 & 3 & 3 & 8 & 3 & 3 & 3 & 5 \\
\hline MRP & $\mu \mathrm{g}^{-1}$ & 1 & 1 & 0 & 1 & 1 & 1 & 0 & 1 \\
\hline TDP & $\mu \mathrm{g} \mathrm{l}^{-1}$ & 1 & 1 & 0 & 5 & 1 & 2 & 0 & 2 \\
\hline $\mathrm{TP}$ & $\mu \mathrm{g}^{-1}$ & 3 & 2 & 1 & 8 & 5 & 4 & 3 & 7 \\
\hline Total Iron & $\mu \mathrm{g}^{-1}$ & 9 & 8 & 3 & 20 & 17 & 17 & 12 & 24 \\
\hline Dissolved Iron & $\mu \mathrm{g}^{-1}$ & 2 & 2 & 1 & 5 & 8 & 3 & 2 & 24 \\
\hline DRSi & $\mathrm{mg} \mathrm{l}^{-1}$ & 1.18 & 1.28 & 0.76 & 1.55 & 0.92 & 0.92 & 0.60 & 1.40 \\
\hline Oxygen & $\mathrm{mg} \mathrm{l}^{-1}$ & 8.50 & 8.33 & 6.88 & 10.26 & 9.06 & 8.92 & 7.87 & 10.84 \\
\hline Chlorophyll- $a$ & $\mu \mathrm{g}^{-1}$ & 1.4 & 1.3 & 0.1 & 4.6 & 6.3 & 4.0 & 0.1 & 14.5 \\
\hline TOC & $\mathrm{mg} \mathrm{l}^{-1}$ & 0.28 & 0.22 & 0.12 & 0.55 & 0.86 & 0.78 & 0.38 & 1.45 \\
\hline TDN & $\mu \mathrm{g} 1^{-1}$ & 338 & 317 & 255 & 551 & 347 & 289 & 238 & 760 \\
\hline $\mathrm{TN}$ & $\mu \mathrm{g} \mathrm{l}^{-1}$ & 431 & 413 & 264 & 719 & 448 & 383 & 275 & 830 \\
\hline
\end{tabular}

(Tab. 3 and 6). Although ammonium concentration in precipitation is relevant, its concentration in remote high altitude lakes is negligible (Marchetto et al. 1994), implying that ammonium is either completely oxidised or taken up by the vegetation. While nitrate uptake produce alkalinity, both oxidation and uptake of ammonium produce acidity. For this reason ammonium must be taken into consideration in the evaluation of the potential acidifying load of precipitation.

The $\mathrm{pH}$ value undergoes frequent fluctuations which are linked to the carbon dioxide concentrations which in turn depend on photosynthetic activity and the aerobic decomposition of organic matter and respiration, this influence being particularly high under the winter icecover. Chlorophyll- $a$ concentrations reach their maximum value in the deep part of the lakes and often under the ice-cover in December, probably when the snow cover is still thin and does not prevent sufficient light penetration. Chlorophyll values (Tab. 6) of Milchsee are in the normal range for oligotrophic alpine lakes (Psenner et al. 1988; Thaler et al. 1991). In Langsee chlorophyll values are sometimes very high and more typical of mesotrophic conditions, despite the low phosphorus concentrations.

Atmospheric depositions have a key role in determining lake chemistry, particularly for lakes with watersheds composed of acidic rocks. Dissolved major ion concentrations were higher in the winter period and lower during summer probably because of dilution due to higher precipitation amounts, while their percentage composition remained more or less constant throughout the year. During winter stagnation a marked increase of the concentrations towards the bottom was registered. The mean concentrations of silica and sulphate also tended to increase during wintertime because of lower dilution. Alkalinity values tended to increase with depth.

\subsection{Long term trends}

\subsubsection{Precipitation chemistry}

In Europe sulphur dioxide emissions increased from the post war years and peaked mainly in the 1960s1970s. Following emission control measures, gradual reductions took place in most countries and especially in western Europe in the 1980s (Mylona 1996). While the reduction in sulphur emissions was substantial, the output of $\mathrm{NO}_{\mathrm{X}}$ changed during the same period very little. It increased in Europe until the mid 1980s and has since then reduced by around $10 \%$. Industry and power stations have given their contribution to the lowering of emissions, for instance lowering the sulphur fraction of the mineral oil products and implementing desulphurisation plants, but the part due to traffic and agriculture has rather increased, even if the output per vehicle has decreased. Reduced sulphur emissions in Europe are leading to decreased atmospheric concentration and deposition levels. These modifications are clearly observable also for the sites of South Tyrol. Atmospheric sulphate levels declined greatly during the last six years, while nitrogen deposition showed first a tendency toward increase up to 1994 and declined only afterwards 

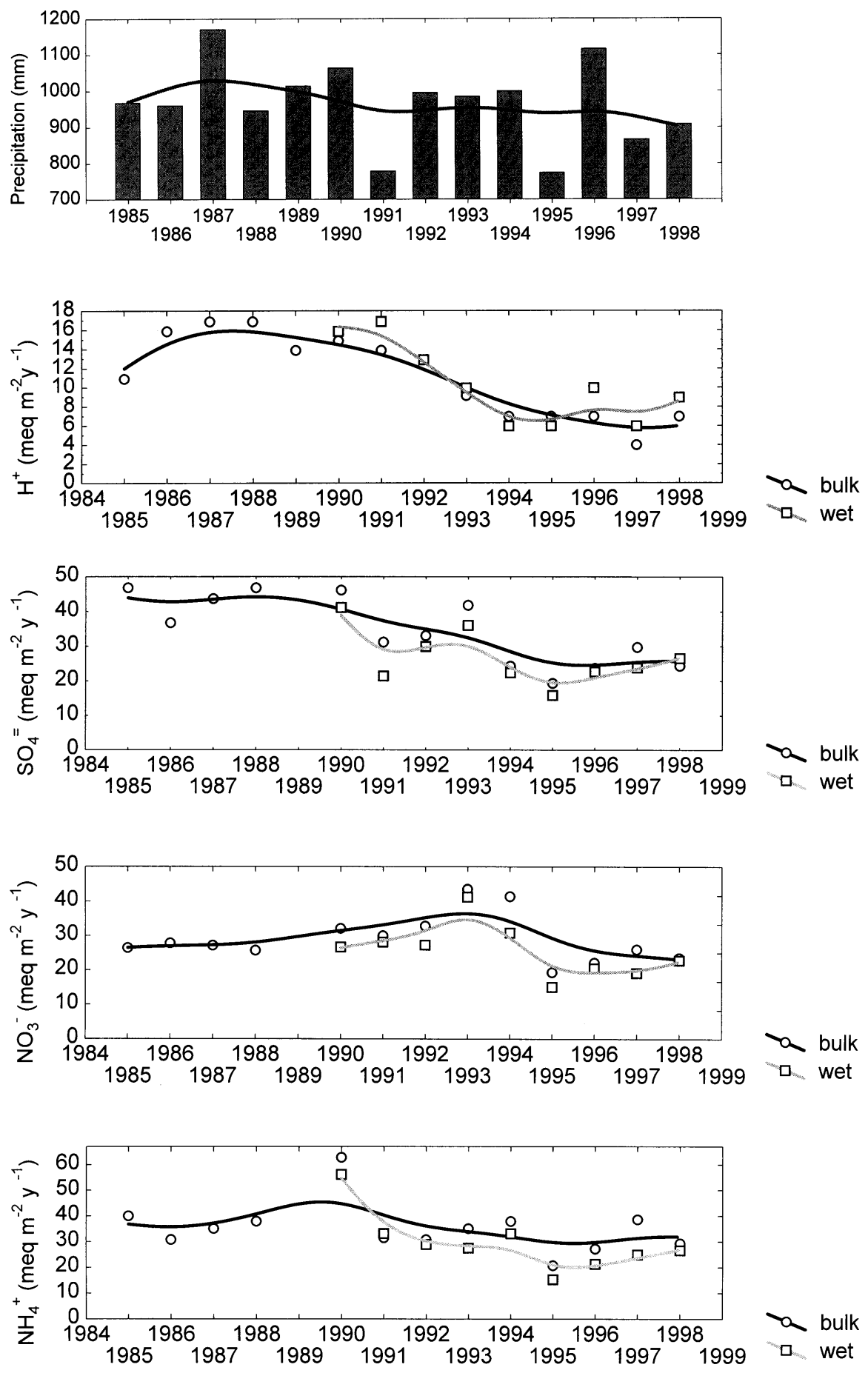

Fig. 5. Yearly precipitation amount and annual average depositions in weekly samples at Ritten, with least squares fitting.

with a subsequent tendency towards a light increase (Fig. 5). The ratio between sulphate and nitrate depositions changed from 2:1 in 1984 to $1: 1$ in recent years.

Ammonia emissions, coming principally from livestock production and as a reaction product of catalysators, showed no significant change. Clean up measures and the reduction of the industrial activity in eastern European countries have also led to a reduction in emissions of alkaline dust particles (Lee 1999). Although the impact of these reductions on the critical loads is marginal, it can partially counteract the lowering of the acidic input. 
Tab. 7. Annual changes in precipitation chemistry. Slope evaluation from linear regression (LR) on seasonally adjusted series and from seasonal Kendall's test (KT); Levels of significance (sig.) $* * *<0.1 \%, * *<1 \%, *<5 \%$.

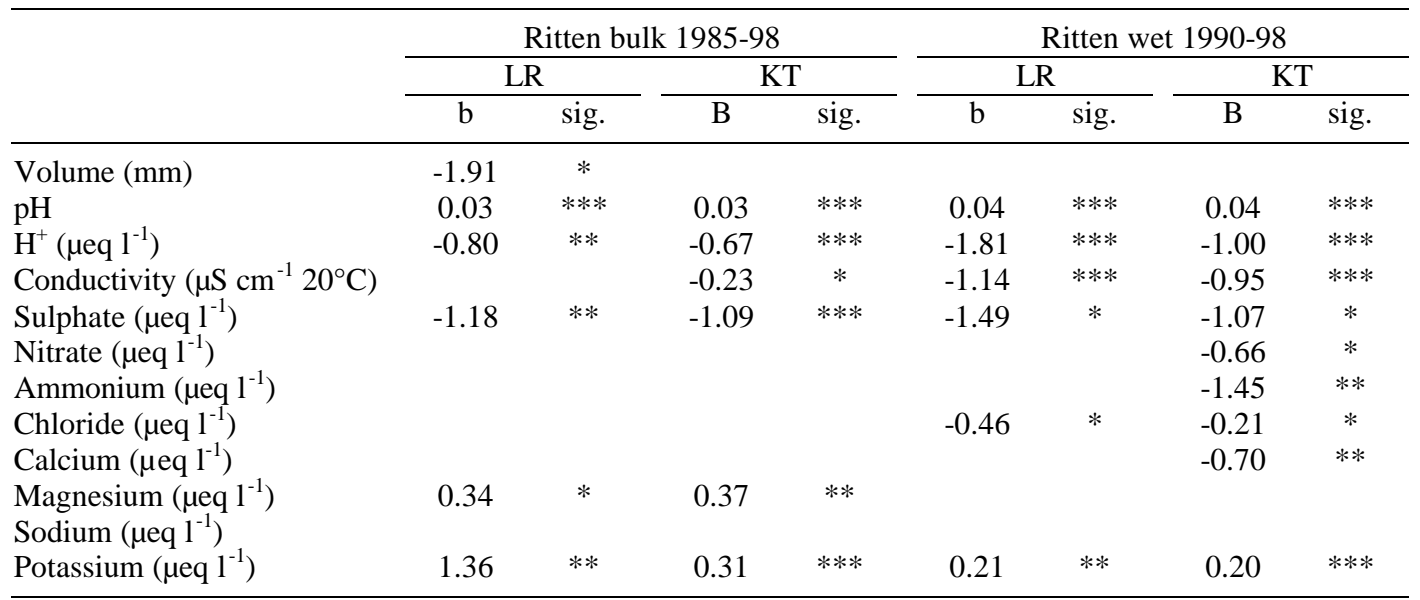
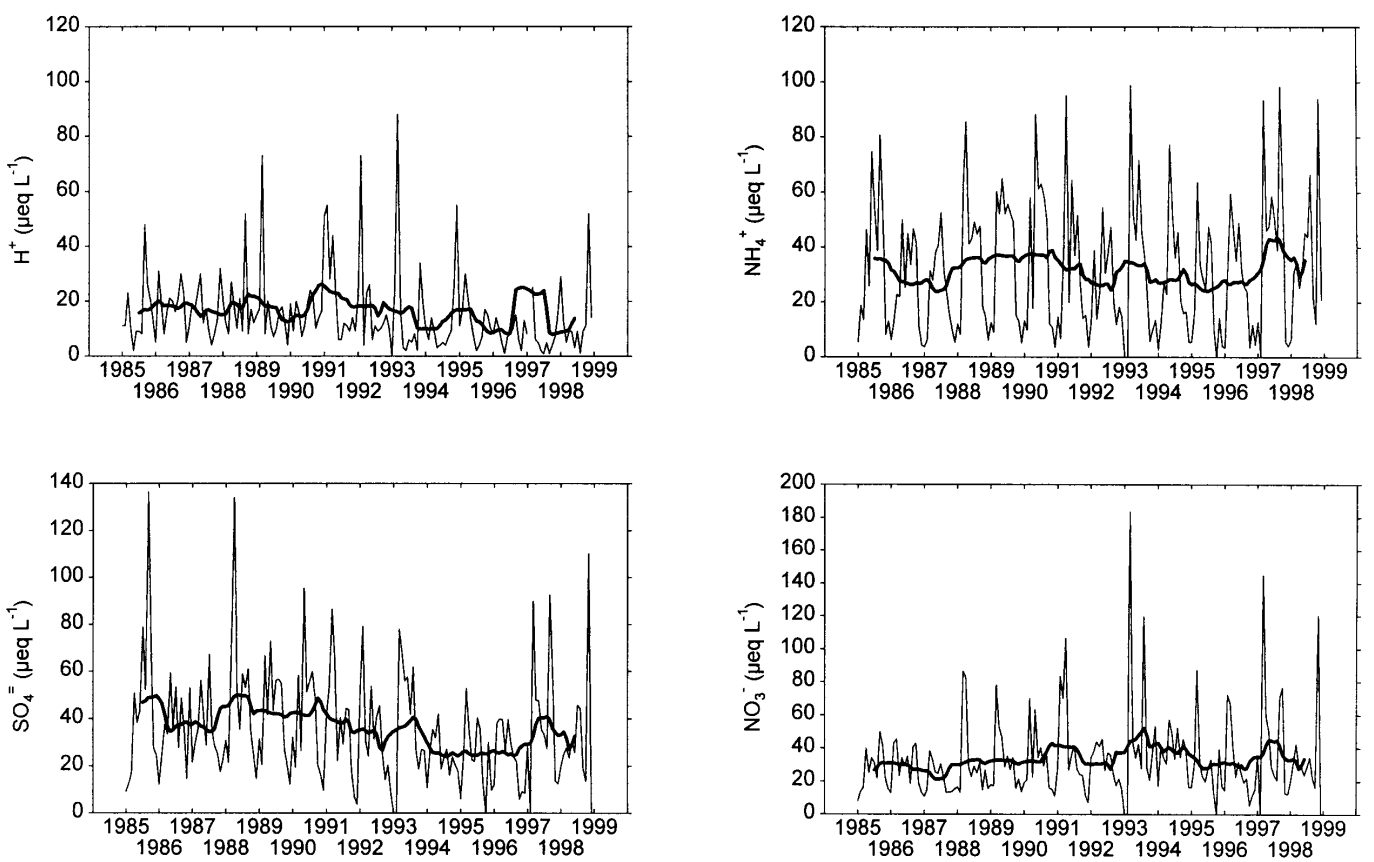

Fig. 6. Long term trends of some chemical variables in atmospheric bulk deposition at Ritten. Monthly average values and twelve point moving average.

Trends and slope evaluation have been analysed with linear regression on deseasonalized monthly data and with seasonal Kendall's test (Hirsch et al. 1982) . The results, expressed as measure unit change per year (Tab. 7), show for both parametric and non-parametric test a very highly significant $(\mathrm{p}<0.1 \%)$ decrease of acidity both for the period 1985-98 in the bulk samples and for the period 1990-98 for the wet samples. The magnitude of this decrease is rather low as the seasonally adjusted series also show (Fig. 6), but the decrease becomes more evident if the annual $\mathrm{pH}$ median values or the proton deposition averages are considered (Fig. 5). The decrease of the sulphate concentrations is highly significant and fails to obtain a better score due to a slight increase in the last two years (Fig. 5). The change of the nitrate concentrations is documented only for the wet samples, where it shows a decrease in the last eight years. Ammonia deposition also showed a declining trend, which however is highly significant only for the wet deposition records and for the non parametric test (Tab. 7, Figs 6 and 7). Also for South Tyrol a decreasing tendency in the calcium deposition values was ob- 
served, which however is highly significant $(\mathrm{p}<1 \%)$ only for the wet samples and for the non parametric test (Tab. 7, Figs 6 and 7). The decrease of the alkaline dust could partly counteract the decline in acidic emission but on the whole, the long term recorded modifications for the atmospheric precipitation chemistry clearly show a decrease of the net total acidifying level.

\subsubsection{Lakes}

The chemistry of the lakes reflects the interaction of the atmospheric acidic loading, the watershed sensitivity, and the changeable inputs of solutes from the watershed. The records of the weighted mean chemical concentrations in the lake water during the last ten years show that marked changes have taken place in the lake's water composition (Fig. 7). Regression analysis shows very highly significant changes for alkalinity, sulphate and nitrate in both lakes and for calcium at Milchsee.
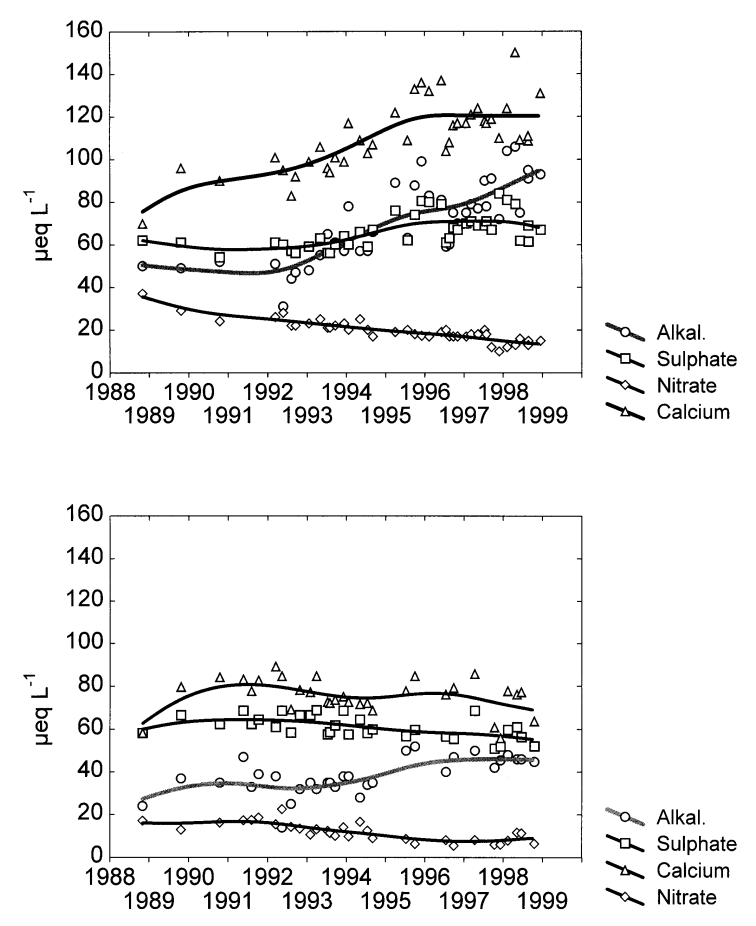

Fig. 7. Weighted mean of the main chemical concentrations in the lake water of Milchsee (above) and Langsee (below).

The most relevant modification is the increase of the alkalinity values $(p=0.000)$ which have almost doubled from 1988 to 1998 in both the lakes. There is good evidence that decreased sulphur atmospheric deposition and the consequent reduction of the acidity will eventually result in alkalinity increases and drive the lakes toward more buffered conditions, but in this case alkalinity has been also greatly enhanced by increased primary production and by increased weathering rate. An increase of the primary production took place for Langsee, documented by the statistically significant increase of the chlorophyll-a concentration (Tab. 8, Fig. 8) and of the phytoplankton biomass (Fig. 8). For Milchsee the increase is not significant, but for both lakes particularly high autumnal values were recorded. The linear regression analysis shows that the $\mathrm{pH}$ increase was not significant, but its variations followed the changes in the primary production. The increased levels of primary production were accompanied by a continuously declining nitrate level which may reflect in-lake biological processes but perhaps also an uptake by the terrestrial vegetation of the watershed, although sparse and mainly composed of pioneer vegetation.

The two lakes differ in so far as sulphate and calcium concentrations are concerned: despite the decrease in sulphate concentration in atmospheric precipitation, the concentration of sulphate but also of calcium increased in Milchsee. In Langsee, sulphate decreased at a rate lower than in atmospheric precipitation, while calcium
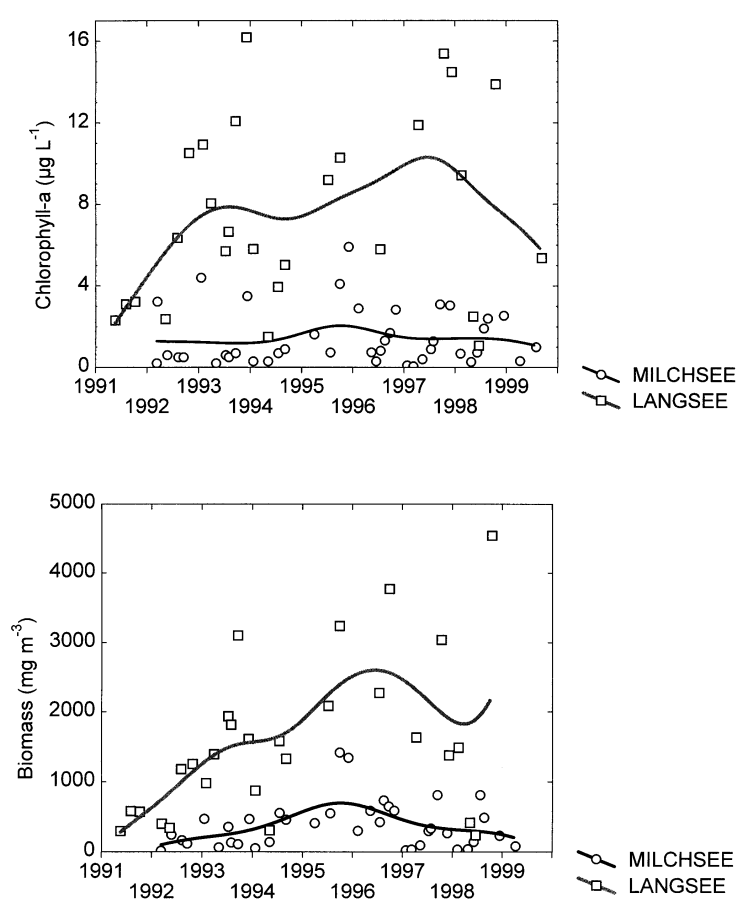

Fig. 8. Distribution of the chlorophyll- $a$ ) concentrations and phytoplankton biomass of Milchsee and Langsee, with least squares fittings.

did not change significantly. The changes in ion concentrations cannot be explained solely by changes in atmospheric deposition and in-lake productivity, but also by increased weathering in the watershed. The differences between the two lakes can be explained by the different input from the weathering due to the different size of the watersheds (the ratio between watershed and lake area is 10 for Langsee and 28 for Milchsee), by different retention times, by the different percentage of glacier within the watershed and by the slightly different lithological composition. 
Tab. 8. Annual changes in lakewater chemistry. Regression results for some parameters at Milchsee and Langsee. ( $\mathrm{B}=$ annual regression coefficient; $\mathrm{r}^{2}=$ coefficient of determination).

\begin{tabular}{|c|c|c|c|c|c|c|}
\hline & \multicolumn{3}{|c|}{ Milchsee } & \multicolumn{3}{|c|}{ Langsee } \\
\hline & B & $r^{2}$ & p-level & $\mathrm{B}$ & $\mathrm{r}^{2}$ & p-level \\
\hline $\mathrm{pH}(1 \mathrm{~m})$ & - & 0.013 & 0.471 & - & 0.006 & 0.652 \\
\hline $\mathrm{pH}(5 \mathrm{~m})$ & - & 0.091 & 0.552 & - & 0.000 & 0.953 \\
\hline $\mathrm{pH}(10 \mathrm{~m})$ & & & & - & 0.003 & 0.760 \\
\hline Alkalinity $\left(\mu \mathrm{eq} \mathrm{l}^{-1}\right)$ & 5.48 & 0.615 & 0.000 & 2.19 & 0.453 & 0.000 \\
\hline Sulphate $\left(\mu \mathrm{eq} 1^{-1}\right)$ & 1.83 & 0.339 & 0.000 & -0.80 & 0.212 & 0.008 \\
\hline Nitrate $\left(\mu\right.$ eq $\left.1^{-1}\right)$ & -1.79 & 0.794 & 0.000 & -0.81 & 0.410 & 0.000 \\
\hline Calcium $\left(\mu \mathrm{eq} \mathrm{l}^{-1}\right)$ & 4.75 & 0.535 & 0.000 & - & 0.050 & 0.219 \\
\hline Chlorophyll- $a\left(\mu \mathrm{g} \mathrm{l}^{-1}\right)$ & - & 0.026 & 0.329 & 0.77 & 0.165 & 0.028 \\
\hline Biomass $\left(\mathrm{mg} \mathrm{m}^{-3}\right)$ & - & 0.134 & 0.489 & 219 & 0.199 & 0.017 \\
\hline
\end{tabular}

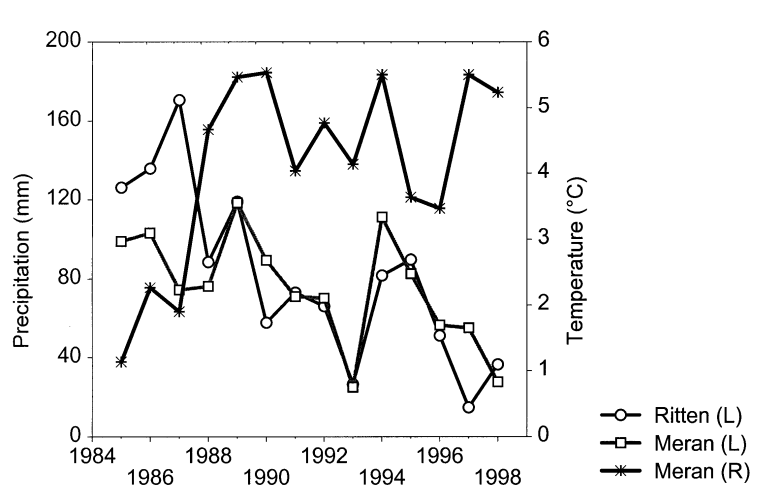

Fig. 9. Winter precipitation $\left(1^{\text {st }}\right.$ quarter) at Ritten and Meran and average winter air temperature in Meran $\left(1^{\text {st }}\right.$ quarter $)$.

A similar increasing trend for the solute concentrations and for productivity was also found in some Austrian high altitude lakes in North Tyrol, and is supposed to be caused by the higher rate of change of the mean temperature in the central Alps than in the northern hemisphere and by the consequently shorter periods of snow and ice cover (Wögrath \& Psenner 1995). For the lakes this would result in an increased concentration of solutes, in an improved exchange of gases and nutrients and in enhanced circulation and light availability (Sommaruga-Wögrath et al. 1997). The average annual air temperature registered in Bozen, during the study period, a significant increase at a rate of $0.06{ }^{\circ} \mathrm{C}$ per year and a higher rate of change was registered for the winter temperature. The average air temperature for the 1st quarter of the year increased significantly both in Bozen and Meran at a rate of 0.14 and $0.16{ }^{\circ} \mathrm{C}$ per year respectively (Fig. 9). The winter amount of precipitation during the same period decreased greatly (Fig. 9), while the precipitation registered for the other seasons did not change significantly (Provincia Aut. Bolzano 1985-96). We suggest that the recent warming trend, producing reduced snowfall and retreating glaciers, is the main factor responsible both for the increased in-lake solute concentrations and for the increase in productivity. Diatoms, pollen and sediment analyses on cores taken on remote high altitude lakes of South Tyrol provided evidence for a strong positive correlation between lakes' $\mathrm{pH}$ and mean air temperature also before industrialisation (Psenner \& Schmidt 1992).

\section{CONCLUSIONS}

Deposition levels sufficient to cause some damage to ecosystems may have occurred in South Tyrol before 1980 , but at the beginning of the present study the sulphur loading was already about one third lower than around 1980 (Mylona 1996). For this reason, the present study was, already in its first stages, registering a recovering situation for the lakes which is still in action for chemistry and above all for the biology, which has longer reaction times.

The reduction of the acidic atmospheric input to the lakes, observed during the past years, produced the expected shift towards more buffered conditions, but some other changes have been observed which are not all linked to changes of the acidic load. Climatic changes involving physical factors (temperature, radiation, amount of precipitation, weathering), nutritional conditions and biological factors (competition, predation) have produced in the last years greater modifications than those to be expected from the decreased acidic input alone. This shows that the acidification trend of sensitive high mountain lakes does not simply depend on the height of the deposition level, but can be influenced by other phenomena as well.

If the two investigated lakes were representative for high mountain lakes in crystalline areas of the province, as suggested by a local survey made in 1988-91 (Thaler et al. 1991), then the buffering capacity of those lakes should have greatly increased in the last ten to fifteen years giving enhanced resistance to the atmospheric acidic inputs.

\section{ACKNOWLEDGMENTS}

We thank Dr. R. Mosello of the Istituto Italiano di Idrobiologia CNR, Pallanza, for suggestions and the critical reading of the paper. The project "Effects of acidification on alpine lakes in the province of Bolzano" and the projects AL:PE and MOLAR were fully or partly founded by the European Commission. 


\section{REFERENCES}

Abrahamsen, G., H.M. Seip \& A. Semb. 1989. Long term acidic precipitation studies in Norway. In: D.C. Adriano \& M. Havas (Eds), Acidic Precipitation. Vol. 1. Case Studies. Springer-Verlag: 137-79.

A.P.H.A., A.W.W.A., W.P.C.F. 1971. Standard Methods for the examination of water and wastewater. Am. Publ. Health Ass., Washington: 874 pp.

Bendetta, G. 1987. Umweltbelastungen durch Luftverschmutzung in Südtirol. Tätigkeitsber. Biol. Lab. Aut. Prov. Bozen, 4: 51-68.

Camarero, L., J. Catalan, A. Boggero, A. Marchetto, R. Mosello \& R. Psenner. 1995. Acidification in high Mountain lakes in central, southwest and southeast Europe (Alps, Pyrennees, Pirin). Limnologica, 25(2): 141-156.

EMEP Co-operative Programme for Monitoring and Evaluation of the Long-range Transmission of Air Pollutants in Europe. 1996. EMEP manual for sampling and chemical analysis. Norwegian Institute for Air Research.

Goltermann, H.L. 1971. Methods for Chemical Analysis of Fresh Waters. - IBP Handbook N8, Blackwell Scientific Publications, Oxford and Edinburgh: 166 pp.

Gran, G. 1952. Determination of the equivalence point in potentiometric titration II. Analyst, 77: 661-671.

Hauhs, M. 1989. Lange Bramke: An ecosystem study of a forested catchment. In: D.C. Adriano \& M. Havas (Eds), Acidic Precipitation. Vol. 1. Case Studies. Springer-Verlag: 275-305.

Hijelbrekke, A.G., G. Lovblad, K. Sjoberg, J. Schaug \& J.E. Skjelmoen. 1995. Data Report 1993, Part 1: Annual summaries. NILU EMEP/CCC/Report 7/95.

Hirsch, R. M., J.R. Slack \& R.A. Smith. 1982. Techniques of trend analysis for monthly water quality data. Water $R e$ sources Research, 18(1): 107-121.

ICP IM Programme Centre. 1998. International Cooperative Programme on Integrated Monitoring of Air Pollution Effects on Ecosystems. Manual for Integrated Monitoring. Finnish Environment Institute.

Istituto di Ricerca sulle Acque. 1972. Metodi analitici per le acque. CNR, Roma

Lee, D.S. \& J.M. Pacyna. 1999. An industrial emission inventory of calcium for Europe. Atmospheric Environment, 33(11): 1687-1697.

Leutelt-Kipke, S. 1934. Hydrochemische Beobachtungen an einigen Südtiroler Mittelgebirgs- und Alpenrandseen. Ber. nat.-med. Ver. Innsbruck, 43/44: 223 - 241.

Leutelt-Kipke, S. 1936: Hydrographische und hydrochemische Beobachtungen an Südtiroler Hochgebirgsseen. Arch. Hydrobiol., 30: 589 - 603.

Lien, L., G.G. Raddum \& A. Fjellheim. 1992: Critical loads of acidity to freshwater-fish and invertebrates. Norwegian Institute for Water Research (NIVA). Report 0-89185: 36 pp.

Marchetto, A., R. Mosello, R. Psenner, A. Barbieri, G. Bendetta, D. Tait \& G.A. Tartari 1994. Evaluation of the level of acidification and the critical loads for alpine lakes. Ambio, 23(2): 150-154.

Marchetto, A., R. Mosello, G.A. Tartari, M. Bianchi, H. Geiss, G. Serrini, G. Serrini Lanza \& H. Muntau. 1999. Performances of analytical methods for freshwater analysis assessed through intercomparison exercices. II. Major ions. J. Limnol., 58(1): 33-41.

Meesenburg, H. \& H.E. Müller. 1998. Critical load of acidity for a forest ecosystem in the Black Forest, Germany. In: Hydrology, Water Resources and Ecology in Headwaters. Proceedings of the Headwater ' 98 Conference held at Meran/Merano, Italy, April 1998. IAHS, 248.
Mosello, R. \& A. Marchetto. 1996. Chemistry of atmospheric wet deposition in Italy: results from a five-year study. Ambio, 25(1): 21-25.

Mosello, R., M. Bianchi, H. Geiss, A. Marchetto, G. Serrini, G. Serrini Lanza, G.A. Tartari \& H. Muntau. 1998. AQUACON-MedBas Project, Subproject No. 5, Freshwater analysis, Intercomparison 1/97. Joint Research Centre. EUR 18075 EN: 66 pp.

Mosello, R., M. Bianchi, M.C. Brizzio, H. Geiss, W. Leyendecker, A. Marchetto, G. Serrini, G. Serrini Lanza, G.A. Tartari \& H. Muntau. 1998. AQUACON-MedBas Project, Subproject No. 6, Acid rain analysis, Intercomparison 1/97. Joint Research Centre. EUR 18135 EN: 64 pp.

Mulder, J., H.F. van Dobben, P.H.B. de Visser, H.W.G. Booltink, \& N. van Breemen. 1987. Effect of vegetation cover (pine forests vs. no vegetation) on atmospheric deposition and soil acidification. In: Acidification and Water Pathways. 1. Proc. UNESCO-IHO Symp. Norway National Commitee for Hydrology, Oslo, Norway: 79-89.

Müller, R. \& O. Widemann. 1955. Die Bestimmung des Nitrations im Wasser. Vom Wasser, 12: 247-271.

Mylona, S. 1996. Sulphur dioxide emissions in Europe 18801991 and their effect on sulphur concentrations and depositions. Tellus Series B Chemical and Physical Meteorology, 48(5): 662-689.

Provincia Autonoma di Bolzano/Alto Adige Ufficio Idrografico. Annali Idrologici 1985-1996.

Psenner, R., K. Arzet, A. Brugger, J. Franzoi, W. Honsig-Erlenburg, F. Horner, W. Müller, U. Nickus, P. Pfister, P. Schaber, \& F. Zapf. 1988. Versauerung von Hochgebirgsseen in kristallinen Einzugsgebieten Tyrols und Kärntens. Bundesministerium für Land- und Forstwirtschaft, Wien: 335 pp.

Psenner, R. \& R. Schmidt. 1992. Climate-driven $\mathrm{pH}$ control of remote alpine lakes and effects of acid deposition. Nature, 356: 781-783.

Psenner, R. 1999. Living in a dusty world: Airborne dust as a key factor for alpine lakes. Water, Air and Soil Pollution, 112: 217-227.

Sommaruga-Wögrath, S., K.A. Koinig, R. Schmidt, R. Sommaruga, R. Tessadri \& R. Psenner. 1997. Temperature effects on the acidity of remote alpine lakes. Nature, 387 : 64-67.

Thaler, B., D. Tait \& G. Bendetta. 1991. Effects of acidification on remote alpine lakes in the Province of Bolzano (South Tyrol, Italy). Final Report. Biologisches Labor Aut. Prov. BZ: 72 pp.

Vogler, P. 1965. Probleme der Phosphatanalytik in der Limnologie und ein neues Verfahren zur Bestimmung von gelösten Orthophosphaten neben kondensierten Phosphaten und organischen Phosphorsäureestern. Int. Rev. ges. Hydrobiol., 50: 35 - 48.

Vogler, P. 1966. Zur Analytik kondensierter Phosphate und organischer Phosphate bei limnologischen Untersuchungen. Int. Rev. ges. Hydrobiol., 51: 775 - 785.

Wagner, R. 1969. Neue Aspekte zur Stickstoffanalytik in der Wasserchemie. Vom Wasser, 36: 263 - 318.

Wathne, B., S.T. Patrick, D. Monteith \& H Barth (Eds). 1995. AL:PE - Acidification of Mountain Lakes: Palaeolimnology and Ecology - AL:PE 1 report April 1991 - April 1993. Ecosystems Research Report 9. European Commission, DG XII, Brussels: 293 pp.

Wögrath, S. \& R. Psenner. 1995. Seasonal, annual and longterm variability in the water chemistry of a remote high mountain lake: acid rain versus natural changes. Water, Air and Soil Pollution, 85: 359-364.

Received: October 1999

Accepted: March 2000 